\title{
The dissection of the wicked servant in Matthew 24:51
}

\author{
David C Sim ${ }^{1}$ \\ Department of Theology, Australian Catholic University \\ Research Associate: Department of New Testament Studies \\ University of Pretoria
}

\begin{abstract}
The dissection of the wicked servant in Mathew 24:51 is a difficult passage to interpret. Most scholars argue that Matthew could not have intended this particular motif to be taken literally, so they propose a metaphorical sense. There are good grounds, however, to question this view. Some neglected evidence suggests that the evangelist did indeed intend this gruesome reference to be taken literally. In Matthew's eschatological schema, wicked church leaders would be punished by dissection at the hands of angelic tormenters in Gehenna.
\end{abstract}

\section{INTRODUCTION}

One of the most difficult synoptic passages to interpret is the reference to the dissection of the servant in the $\mathrm{Q}$ parable of the good or wicked servant (Mt 24:45-51//Lk 12:42-6). Despite some verbal differences, the Matthean and Lucan versions of this pericope are substantially similar and each makes the same point. The message of the parable that those whom the master has set over his household must act with propriety during his absence carries the concrete meaning that the ones in positions of authority in the Christian community must act properly in the period of Jesus' absence between the resurrection and the parousia. As a means of encouraging or enforcing the obedience of those concerned, this Q tradition emphasises the eschatological rewards and punishments which Jesus will bring when he returns at the end of the age. The good servant who does the will of his

\footnotetext{
1 Dr David C Sim participates as associate in the research project "Biblical Theology and Hermeneutics", directed by Prof Dr Andries G van Aarde, Department of New Testament Studies, Faculty of Theology, University of Pretoria.
} 
master will receive his due reward upon his master's return and be put in charge of all his possessions. Conversely, the wicked servant who counts on his master's delay and abuses his position of trust will be severely punished for his sins.

According to both synoptic texts, the fate of the wicked servant is rather bizarre to

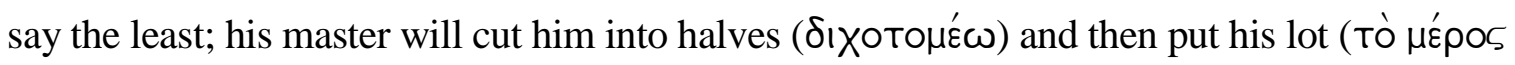
aútoû) with the unfaithful (so Luke) or with the hypocrites (so Matthew). It is generally agreed that the $\mathrm{Q}$ material finishes at this point and that Matthew has appended a favourite expression, "there men will weep and gnash their teeth" ( $\operatorname{cf} 8: 12 ; 13: 42,50,22: 13 ; 25: 30)$. This addition highlights even more the terrible nature of the final punishment. What will concern us in this study is the strange motif of the servant's dissection, especially in the understanding of Matthew.

\section{THE STORY OF AHIQAR}

A good many scholars have accepted the authenticity of this parable, but there is no agreement as to its exact meaning on the lips of Jesus. Both Jeremias (1972:57) and Manson (1949:119) suggest that the bizarre part of the tradition, the dissection of the wicked servant, resulted from a mistranslation of the original words of Jesus, though they disagree over the precise Aramaic words which Jesus spoke. Other scholars are prepared to let this odd motif stand, explaining it on the grounds that Jesus was familiar with and influenced by the story of Ahiqar. This ancient story was composed in Aramaic in the sixth or seventh century BCE. The earliest extant version of this tale appears in a fifth century BCE Aramaic manuscript found at Elephantine. This manuscript unfortunately is not complete, but there are later and more detailed recensions in Arabic, Armenian, Syriac and other languages (see Lindenberger 1985:480).

In the later versions of this story, the childless Ahiqar, counsellor to the kings of Assyria, adopts his nephew Nadan as his son. Ahiqar places Nadan in charge of his household and his servants, but the nephew returns this kindness by wasting his money and beating the servants (3:1-2). In response to this, Ahiqar sends Nadan from his house. Nadan then plots his revenge, which he accomplishes by informing the Assyrian king that Ahiqar is involved in a plot to overthrow him. Ahiqar is sentenced to death, but he manages to escape this fate by convincing his executioner to hide him. In the meantime Nadan returns to Ahiqar's house, and proceeds to eat and to drink with the drunken and to beat the servants 
again (4:15). The righteous Ahiqar is eventually vindicated, and the wicked Nadan receives his just deserts by swelling up so much that he bursts apart and dies (8:38). The Arabic version continues that for his great sins Nadan was sent to hell.

There are a number of interesting parallels between the story of Ahiqar and the parable in Mt 24:45-51 and Lk 12:42-6. Both the wicked servant of the parable and Nadan completely abuse their positions of responsibility by eating and drinking with the dissolute and beating their servants. Moreover, both of them meet a particularly grisly end when their respective masters return. The wicked servant is cut into two, while Nadan bursts apart. These parallels convinced some earlier scholars that Jesus modelled his parable on this ancient and well-known story. J R Harris, F C Conybeare and A S Lewis (1913a:Ixiii; original italics), for example, jointly maintained that "A new volume (i e Ahiqar) has...been added to our Lord's library." 2 While it is certainly possible that Jesus (or the transmitters of Q) had been influenced by the story of Ahiqar, there is need for some caution here.

Even if we grant that there is a case of dependence with regard to these two traditions, a problem arises in identifying the direction of influence. The pre-Christian recension of the story of Ahiqar does not contain the themes which are paralleled in the Q parable. Nothing is said of Nadan's carousing and mistreatment of his servants, and the manner of his death is not described. These motifs appear in the later recensions which were copied and transmitted by Christian scribes. While it is possible that these themes were part of the original Aramaic text, which is sadly incomplete, it is just as possible that these motifs were introduced to the Ahiqar story by later Christian copyists who noted a general parallel between the sin of Nadan and the sin of the wicked servant in the Gospel parables. In the light of this evidence, Lindenberger (1985:479-507) makes the reasonable point that "The conclusion drawn by some older writers that Jesus and the evangelists must have known Ahiqar goes considerably beyond the evidence". In addition to this, the death of Nadan in the Ahiqar tale does not bear a close relationship to the punishment of the wicked servant in the synoptic parable. It more closely resembles the death of Judas in Acts 1:18, where the betrayer of Jesus falls over and his stomach bursts open, though again it is impossible to

\footnotetext{
2 These scholars make a similar claim in Harris, Conybeare \& Lewis (1913b:719). In agreement with the judgement of these three scholars are Davies \& Allison (1997:390-391), though Davies \& Allison erroneously ascribe the view to the editor of the volume, R H Charles.
} 
determine whether either of these traditions might have influenced the other. ${ }^{3}$ We may conclude that the influence of the story of Ahiqar on this Q parable, at any stage of its early transmission, remains inconclusive.

\section{THE METAPHORICAL INTERPRETATION OF THE SER- VANT'S DISSECTION}

For the remainder of this study I wish to focus on this parable within the Gospel of Matthew. More specifically I want to examine the evangelist's understanding of the punishment of the wicked servant. How did Matthew intend the dissection of this figure to be taken? Most Matthean commentators argue that Matthew could hardly have taken $\delta ı$ Хото ${ }^{\prime} \varepsilon \omega$ literally. Although they might concede that the punishment of dissection was practised in the Jewish tradition (cf 1 Sam 15:33; Heb 11:37; Lives of the Prophets. Isaiah 1:1; Ascension of Isaiah $5: 1$ ) and that the execution of slaves was not uncommon in the ancient world (see Beavis 1992:42-43; and literature cited there), they argue nonetheless that a literal reading of this motif would involve the absurd proposition that a severed body would be fit for further punishment (see, e. g., Harrington 1991:244; cf Manson 1949:118; Donahue 1988:100). They therefore opt for a metaphorical rather than a literal reading of this word.

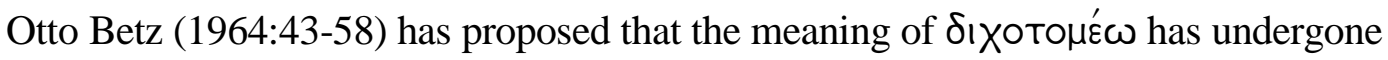
change during the course of its transmission. ${ }^{4}$ The parable in Mt 24:45-51a//Lk 12:42-6 is based upon Ps 37, and originally the description of the servant's punishment referred to the separation or cutting off of the wicked at the eschaton. In the context of Matthew, however, this single end-time event has become two distinct stages in the fate of the sinner. The splitting of the servant symbolises the grisly death of the wicked (cf Acts 1:18 in reference to Judas), while the allusion to placement with the hypocrites stands for his consignment to eschatological punishment after death. The major problem with Betz's interpretation is that

\footnotetext{
${ }^{3}$ Harris, Conybeare \& Lewis (1913a:719) note the parallel between the death of Judas in Acts and the death of Nadan in the Ahiqar tale, but they offer no view on possible dependence. Lindenberger (1985:487) also compares the two episodes, and concludes that each has made use of a common narrative convention which describes the unpleasant end of the wicked in these terms. He notes as further parallels the death of the dragon in Bel and the Dragon, an addition to the book of Daniel (v 27), and the demise of the serpent in the Acts of Thomas 33.

${ }^{4}$ Betz's interpretation of this material seems to be followed by Hagner (1996:724-725).
} 


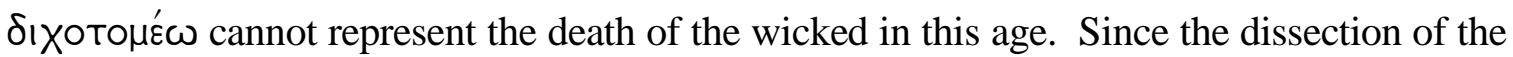
servant takes place after the return of the master, that is following the parousia of Jesus, this activity must have an eschatological referent (in agreement with Blomberg 1990:191 and Charette 1992:152 n 2). It is this point which makes it inherently unlikely that Matthew saw any connection between the end-time punishment of the wicked servant and the death of Nadan in the story of Ahiqar (if indeed we assume he knew the latter).

Other scholars argue that Betz's understanding of this material at the pre-Matthean stage better suits the evangelist's interpretation. Taking separate' or "to exclude", they argue that Mt 24:51 refers to exclusion or ex-communi-cation from the community with the eschatological consequences this involves. Since the offender is cut off from the righteous, he will share the eschatological lot of the wicked (the hypocrites). In support of this interpretation, appeal is usually made to a number of Qumran texts which speak of enforced separation of the offender from the community and/or their sharing the fate of the wicked as a result of this. The most cited parallel is 1QS 2:16-17 which reads; "God will set him apart for evil, and he will be cut off from the midst of all the sons of light...He will put his lot in the midst of the accursed forever (cf also 1QS 1:10-11; 6:24-5; 7:1-2, 16; 8:21-3). ${ }^{5}$

While this interpretation has the advantage of attending to the eschatological context

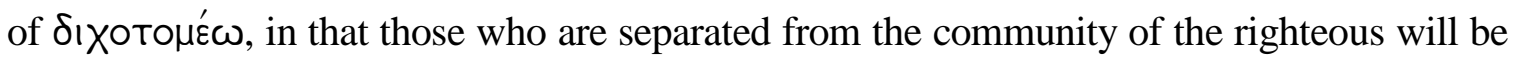
separated from it at the time of the judgement, it has been justly criticised as an unwarranted refinement of the text. These critics note that when Matthew depicts the fate of the wicked elsewhere in the Gospel he does so in extremely harsh terms. In his eschatological scheme the wicked are not just excluded from the realm of the righteous; they are sent to Gehenna where they will be punished for eternity by fire (cf 3:7-12; 5:22, 29; 7:19; 10:28; 13:42, 50; $18: 8-9 ; 23: 15,33 ; 25: 41){ }^{6}{ }^{6}$ On account of the evangelist's rather severe view concerning the

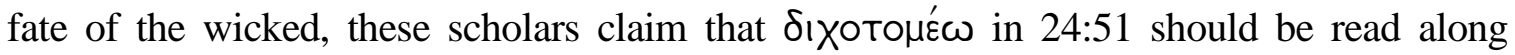
similar lines. It does not refer to a literal dissection of the offender, but to the severity and

\footnotetext{
5 For this general view, though with some differences in detail, see Donahue (1988:100); Harrington (1991:344); Hill (1972:325); Schweizer (1976:463) and Jones (1995:439-440).

${ }^{6}$ For further discussion of this theme, see Sim (1996:129-140).
} 
harshness of his eternal punishment. ${ }^{7}$ This interpretation is certainly more plausible than the alternative views, but there are good grounds for questioning whether it too does sufficient justice to the intentions of Matthew.

It is clear from the above survey of scholarly views that all interpreters of this Matthean passage have simply assumed that the evangelist could not have intended the reference to the dissection of the servant to be taken literally. He must have meant this motif to be taken figuratively and, as we have seen, scholars have speculated on the precise symbolism involved. But on what grounds is the initial assumption justified? Why is the possibility excluded out of hand that Matthew might have accepted that the wicked in the Christian community could have been dissected at the time of the judgement and then punished further? No real attempt to answer this question is ever given, but it seems that scholars have made decisions about the beliefs of the evangelist on the basis of their own standards and worldviews. Since the scenario presented in Mt 24:51 seems both im-possible and bizarre to modern readers, it is immediately assumed that Matthew must have thought in similar fashion.

This approach, however, is highly questionable. It hardly needs saying that the evangelist was not a citizen of the twenty-first century technological and scientific world; he was a first century Hellenistic Jew whose understanding of the world was completely different from our own. Like many or all of his contemporaries, Matthew believed a good many things that do not sit easily with the scientific and technological worldview of the twenty-first century. He doubtless accepted that the world had been created in six days, that God had parted the Red Sea, that he caused the sun to stand still in the time of Joshua, and so on. He also believed in the existence of Satan and his horde of evil angels, and he accepted that these demonic beings could inhabit the bodies of unfortunate people. In terms of his eschatological beliefs, it is clear from the Gospel passages cited above that Matthew believed without hesitation that the wicked would be punished forever in a fire that would burn but not consume. While such a notion might seem illogical, absurd and even offensive to many in the modern world, this merely illustrates the gulf between this first-century figure and his modern interpreters. Matthew was a child of his time, and he believed in a God with limitless power who could make the impossible happen. If his God had the power to create

\footnotetext{
7. So, with varying differences in detail, Blomberg (1990:191-192); Charette (1992:152); Beare (1981:479); Marguerat (1981:534-535); Gnilka (1988:344); Scott (1990:210) and Gundry (1994:497).
} 
a fire of torment, which burnt without destroying, then he could certainly accomplish with little difficulty the dissection of the wicked and later subject them to further punishment. There is therefore no valid reason to deny the possibility that Matthew might have taken quite literally the reference to dissection in Mt 24:51. The remainder of this study will present some neglected evidence that he may indeed have done so.

\section{A LITERAL INTERPRETATION}

Let us begin by noting the little-known story of Susanna, one of the additions to the canonical book of Daniel. This short story contains an interesting reference to the postmortem dissection of the wicked, and it therefore provides the closest parallel to the $\mathrm{Q}$ motif in Mt 24:51 and Lk 12:46. ${ }^{8}$ In this narrative Susanna, the beautiful and virtuous wife of Joakim, is lusted after by two elders of the people who spy on her as she walks in her garden. One day they approach her as she is bathing and present her with a rather unpleasant choice; either she consents to have intercourse with them or they will testify that they witnessed her committing adultery. Susanna refuses and she is duly charged with the crime. The elders relate a concocted story to the people about Susanna's adultery with a young man, and they are believed because of their authoritative position in the community. Susanna is condemned to death, and she prays to God to vindicate her.

God then calls upon Daniel to take the part of Susanna. He interrogates each elder individually, and exposes the inconsistencies in their stories. As he reveals the lie of the first elder, Daniel says, 'You have lied against your own head...for the angel of God has received the sentence and will immediately split you into two" (v 55). His words to the second elder are similar, 'Your have also lied against your own head...for the angel of God is waiting with a sword to cut (or saw) you in two, that he may destroy you both" (v 59). Having been exposed as false witnesses, the elders are then put to death according to the law. Susanna is thus vindicated and Daniel grew in esteem from that day forth. The important point for our purposes is that the gruesome punishment inflicted by the angel is clearly post-mortem or eschatological. The angel does not take the lives of the sinful elders; rather, they are

${ }^{8}$ This is noted but not discussed in detail by Jones (1995:440). A passing reference to the Susanna material is also found in the discussion of Mt 24:51 by Davies \& Allison (1997:390 n 122) and Luz (1997:463-464 n 29). It is of further interest that a connection between Mt 24:45-51 and the Susanna story was noted by Origen in his famous commentary on Matthew (see Engel 1985:21-22). 
executed by the outraged community after their perjury has been exposed, and the angel of God exacts his vengeance after they are dead. ${ }^{9}$

It is certain that Matthew and his intended readers knew the story of Susanna and the horrific fate of her accusers. The evangelist refers explicitly to the book of Daniel in 24:15, and the Susanna narrative was an integral part of the text of Daniel by the time Matthew wrote. All the additions to Daniel, including the story of Susanna, had been incorporated around $100 \mathrm{BCE}$, roughly 200 years before the evangelist composed his Gospel (see Collins 1993:437-438 and Moore 1977:28-29). By the time of Matthew, they were accepted as sacred or authoritative writings by all Jews (Hartman \& Di Lella 1978:83-84). For such a keen interpreter of scripture as Matthew doubtless was, the parallels between the story of Susanna and the parable of the good or wicked servant which he inherited from Q would have been immediately obvious (Jones 1995:440).

In the former the elders sin greatly by lusting after Susanna, but they compound this sin by abusing their authoritative positions and bearing false witness against her. According to Mt 24:45-51 the wicked servant errs initially in thinking his master has been delayed, and he then abuses his position of authority by beating his fellow servants and leading an immoral life. The elders are hypocritical in so far as they charge Susanna with unchastity, while they themselves are unchaste in their thoughts and actions. In the Matthean parable, the wicked servant is by implication guilty of hypocrisy, since his lot is to be put with the hypocrites (Charette 1992:152). And just as the elders receive an eschatological punishment by dissection at the hands of an avenging angel, so too is the wicked servant split into halves upon the return of Jesus at the end of the age. The major point in each narrative is basically the same. Those who are guilty of hypocrisy and/or who sin by misusing their power and influence in the community are destined to receive the eschatological punishment of dissection.

One apparent disparity between these texts concerns the agent of this gruesome eschatological punishment. In the story of Susanna it is an angel of God, while the parable of the good or wicked servant states that the returning master (i e Jesus) performs this task. Does this mean that Matthew accepted that upon his return Jesus himself would dispense

9 This eschatological aspect of the angel's punishment is missed by Collins (1993:434), who argues that the activity of the angel threatened by Daniel in v 55 does not subsequently take place. 
this punishment to those unfaithful leaders of his church? This seems unlikely. According to Matthew's eschatological scheme elsewhere in the Gospel, Jesus will arrive from heaven with an army of angels $(16: 27-8 ; 24: 30-1)$ in order to preside over the final judgement on his throne of glory $(19: 28 ; 25: 31-46$; cf $7: 21-3)$. Jesus is therefore the final judge who dispenses both rewards and punishments, but he does not himself participate in the execution of the sentence. This task falls to others.

In a previous study I argued that Matthew knew the common apocalyptic tradition that following the final judgement the wicked would be punished by angelic torturers who reside in the place of punishment (i e Gehenna) (Sim 1999:693-718). This rather gruesome tradition is represented in 18:34, the final verse of the parable of the unforgiving servant. In this verse, which Matthew himself created, the king hands over the wicked servant to the torturers. For Matthew the wicked servant is once again a wicked Christian leader who acts irresponsibly, while the torturers clearly symbolise angels of eschatological torment (see Sim 1999:707-715). Some scholars have noted in passing the similarity between Mt 18:34 and 24:51 in the brutality of punishment (see Beare 1981:479; Charette 1992;152; Davis \& Allison 1997:390 n 124). However, we need to press this link much more closely. Both texts refer to the eschatological punishment of wicked Christian officials by means of torture. One mentions the agents of torment, while the other specifies the method used. Since 18:34 stipulates that those who mete out punishment to sinful Christian leaders are angelic torturers, it stands to reason that in Mt 24:51 it is not Jesus the judge who slices the wicked servant in two, but representatives of this group of avenging angels. This means that we must take $\delta ı$ хотон'́ $\omega$ in a causative sense; Jesus causes the dissection of the wicked servant by ordering his angels to impose this punishment, but he does not perform the action himself.

If this understanding of the text is correct, then we have a further correspondence between the story of Susanna and the parable of the good or wicked servant in Mt 24:45-51. In both texts the dissection of the wicked is carried out by avenging angels. This point reinforces the previous conclusion that, given Matthew's knowledge of the Susanna tale and its correspondences with the Q tradition he inherited, he probably interpreted the latter on the basis of the former. Just as the Jewish leaders abused their positions of trust and authority and met with angelic dissection for their sins, so does the same fate await those 
leaders in the Christian community who act in similar fashion. The splitting in two of the wicked Christian official is not therefore metaphorical; it is meant literally, just as it is in the Susanna story.

But an important question remains. How can a dissected body be fit for further punishment? In Mt 24:51 the church official who is split in two is to be put with the hypocrites where he will weep and gnash his teeth. This place of punishment is doubtless Gehenna. That Matthew could envisage both dissection and further torment in Gehenna is not problematical. The Jewish and Christian apocalyptic traditions are replete with references to avenging angels whose acts of torture stand in addition to the usual torment provided by the fiery place of eternal punishment. ${ }^{10}$ Close parallels to this Matthean theme are found in the later Christian apocalyptic literature, where wicked church officials receive particular punishments befitting their crimes. In the Apocalypse of Paul, for example, evil presbyters are continually strangled and pierced by angels of torment in the fiery regions, and other punishments at the hands of similar tormenters are reserved for sinful bishops and lectors (chs 34-6). Matthew seems to provide a very early example of this gruesome motif.

\section{CONCLUSIONS}

We may now draw some conclusions. In attempting to discern the meaning of the splitting of the wicked servant in Mt 24:51, scholars have by and large missed the precise point which the evangelist was making. While the story of Ahiqar might have influenced the parable of the wicked servant at some stage of its transmission, though this is by no means certain, it seems to have played little or no part in Matthew's interpretation of the punishment of the offender. The reference to eschatological dissection in Mt 24:51 in no way compares with the death of Nadan in the Ahiqar tradition; the latter text finds its closest New Testament parallel in the death of Judas in Acts.

The major scholarly views concerning this tradition, that Matthew intended the reference to dissection either to symbolise the exclusion of the wicked from the righteous community or to represent the horrors of eschatological punishment, must also be called into question. The former does not take seriously enough the evangelist's many statements

${ }^{10}$ For a brief review of angelic torturers in these traditions, see Sim (1999: 696-699). 
concerning the fiery fate which awaits the wicked, and the latter, while certainly more in tune in Matthew's eschatology, seems not to be precise enough. Both of these views make the mistake of seeking a figurative or metaphorical sense for $\delta ı$ Хото $\mu \varepsilon \omega$ on the assumption that Matthew could not have taken it literally.

This study has argued that such a literal interpretation is both possible and warranted. Matthew accepted the tradition, found in both Jewish and Christian apocalyptic circles, that avenging angels would play an integral part in the eschatological punishment of wicked Christians (cf 18:34). In 24:51 the evangelist makes the point that Jesus would cause these angels to punish these disobedient Christians by slicing them in two. A similar tradition of angelic tormenters who dissect the wicked is found in the story of Susanna, one of the additions to the canonical book of Daniel and a text that was known to and revered by Matthew and his community. In the light of this and other close parallels between the parable in Mt 24:45-51 and the tale of Susanna, it can be deemed very probable that Matthew read the $\mathrm{Q}$ tradition he inherited in the light of the Susanna story. Just as the evil elders abused their positions of power and responsibility and were cleaved in two by avenging angels as a result, so too would those leaders in the Christian community who abused their positions be given the same eschatological punishment.

In taking the reference to the dissection of the wicked servant literally and not figuratively, modern readers are presented with a view which is both uncomfortable and rather bizarre. On the one hand, feelings of discomfort arise in view of the harshness of the punishment of dissection which, from a modern standpoint, seems not to fit the crime. On the other hand, the very idea that a dissected body could then be fit for further punishment in the fires of Gehenna seems to strain credulity. In the light of these considerations, it is perhaps understandable that scholars have tried to tone down the meaning of Mthew 24:51. But we should never make the mistake of assuming that what seems unjust, bizarre and even illogical to us was considered in similar terms by the evangelist and his intended readers. These early Christians belonged to a different world, the first century Mediterra-nean world, and they readily accepted contemporary ideas about crime and punishment and about the power and justice of God which have no place in our modern world with its science, technology and its emphasis on legal and prison reform ${ }^{11}$. Whether we agree with it or not,

\footnotetext{
${ }^{11}$ Beavis (1992:42-43) well makes the point that while the punishment of the servant by dissection would offend many modern readers as excessive, ancient readers would have not been shocked in the slightest by this idea.
} 
the complete message of Matthew, both the acceptable and the unacceptable parts of it, deserves to be heard by his modern interpreters. While this might not be comfortable, it is exegetically necessary.

\section{Works consulted}

Beare, F W 1981. The Gospel according to Matthew. Oxford: Basil Blackwell.

Beavis, M A 1992. Ancient slavery as an interpretive context for the New Testament servant parables with special reference to the Unjust Steward (Lk 16:1-8). JBL 111, 37-54.

Betz, O 1964. The dichotomized servant and the end of Judas Iscariot. RevQ 5, 43-58.

Blomberg, C L 1990. Interpreting the parables. Downers Grove, I11: InterVarsity Press.

Charette, B 1992. The theme of recompense in Matthew's Gospel. Sheffield: Sheffield Academic Press. (JSNTSS 79.)

Collins, J J 1993. Daniel. Minneapolis: Fortress Press. (Hermeneia.)

Davies, W D and Allison, D C 1988/1991/1997. A critical and exegetical commentary on the Gospel according to Saint Matthew. 3 vols. Edinburgh: T \& T Clark. (ICC.)

Donahue, J R 1988. The gospel in parable. Philadelphia: Fortress Press.

Engel, H 1985. Die Susanna-Erzählung: Einleitung, Übersetzung und Kommentar zum Septuaginta-Text und zur Theodotion-Bearbeitung. Göttingen: Vandenhoeck \& Ruprecht. (OBO 61.)

Gnilka, J 1986/1988. Das Matthäusevangelium. 2 vols. Freiburg: Herder. (HTKNT.)

Gundry, R H 1994. Matthew: A commentary on his handbook for a mixed church under persecution. $2^{\text {nd }}$ edition. Grand Rapids: Eerdmans.

Hagner, D A 1993/1996. Matthew. 2 vols. Dallas: Word Books (WBC 33a/33b.)

Harrington, D J 1991. The Gospel of Matthew. Collegeville: Liturgical Press. (Sacra Pagina 1.)

Harris, J R, Conybeare, F C \& Lewis, A S 1913a. The story of Ahikar. Cambridge: Cambridge University Press.

Harris, J R, Conybeare, F C \& Lewis, A S 1913b. The story of Ahikar, in Charles, R H (ed), The Apocrypha and Pseudepigrapha of the Old Testament. 2 vols. Oxford: Clarendon. 
Hartman, L F \& Di Lella, A A 1978. The Book of Daniel. Garden City: Doubleday. (AB 23.)

Hill, D 1972. The Gospel of Matthew. London: Marshall, Morgan \& Scott. (NCBC.)

Jeremias, J 1972. The parables of Jesus. London: SCM.

Jones, I H 1995. The Matthean parables: A literary and historical commentary. Leiden: Brill. (NT.S.)

Lindenberger, J M 1983/1985. Ahiqar: A new translation and introduction, in Charlesworth, J H (ed.), The Old Testament Pseudepigrapha. 2 vols. London: Darton, Longman and Todd.

Luz, U 1985/1990/1997. Das Evangelium nach Matthäus. 3 vols. Zürich: Benziger Verlag. (EKKNT.)

Manson, T W 1949. The sayings of Jesus. London: SCM.

Marguerat, D 1981. Le Jugement dans l'évangile de Matthieu. Geneva: Labor et Fides. (Le Monde de la Bible.)

Moore, C A 1977. Daniel, Esther and Jeremiah: The additions - A new translation with introduction and commentary. Garden City: Doubleday. (AB 44.)

Schweizer, E 1976. The good news according to Matthew. London: SPCK.

Scott, B B 1990. Hear then the parable: A commentary on the parables of Jesus. Minneapolis: Fortress Press.

Sim, D C 1996. Apocalyptic eschatology in the Gospel of Matthew. Cambridge: Cambridge University Press. (SNTSMS 88.)

Sim, D C 1999. Angels of eschatological punishment in the Jewish and Christian apocalyptic traditions and in the Gospel of Matthew. HTS 55, 693-718. 